I favour $T_{58 E}$ primarily because $I$ believe that it more closely represents actual vapour-pressuretemperature measurements as determined in the laboratory. I feel this is true not only concerning the $\lambda$-point pressure and the region between $4.2^{\circ} \mathrm{K}$. and $5 \cdot 2^{\circ} \mathrm{K}$., as $\mathrm{I}$ have discussed in some detail, but also of the region below $4 \cdot 2^{\circ} \mathrm{K}$. as well. I consider it extremely reassuring that a single equation, such as equation (1), can fit the results of several independent investigators over so wide a temperature range with such a remarkably small mean deviation. In short, if the temperature scale is to be based on the helium $p-T$ relation, I prefer a scale derived from data and procedures which directly match those used in obtaining temperatures in everyday experiments.

It is, of course, very desirable to tie everything up in one package, to obtain with equation (3) a complete thermodynamic description of helium-4 along the saturation curve and thereby arrive at a temperature scale. Above $4 \cdot 2^{\circ} \mathrm{K}$. it is at present out of the question to employ the method of van Dijk since the necessary data do not exist. Below $4 \cdot 2^{\circ} \mathrm{K}$. we have seen that there are uncertainties inherent in the thermal and state data such that an accurate temperature scale can be obtained only through reliance upon experimental $p-T$ data as a guide.

From the above discussion it can be seen that a single scale could have been derived by combining $T_{L_{55}}$ and $T_{55 E}$ and retaining the more favourable features of each. Above $4.2^{\circ} \mathrm{K}$. it is undoubtedly best to represent the scale with equation (1). Below $4 \cdot 2^{\circ} \mathrm{K}$., equation (3) could be made to fit the experimental vapour-pressure measurements through utilization of the considerable compliance in the thermal and state data (Table 1). This would essentially amount to using the numbers of $T_{55} E$ and the form of $T_{L_{s s}}$ without compromising the stated accuracy of any of the pertinent experimental data. Had such a scale been presented in place of the other two, it would have undoubtedly been favourably received; the merger can still be effected, but not without considerable effort. Lacking this reconciliation, we are forced to decide between the form and the numbers. I believe it is safe to assert that cryogenic experimenters attach more importance to the latter. The numbers exist in the tables of $T_{\mathrm{s} s E}$, and I recommend that these be used.

The arrival at the above conclusion is not tanta. mount to a proclamation of victory for either side, for the real question of which scale is overall closer to the thermodynamic scale cannot be answered on the basis of the existing evidence. It does, however, present the more reasonable interim scale for practical use and allows all concerned to withdraw from battle and go about the business of obtaining new information necessary for determining a thermodynamic scale.

I wish to state that, though the above decision was arrived at independently, my confidence in it has been bolstered by the concurrence of the staff members of the Cryogenics Group, Los Alamos Scientific Laboratory, namely, E. F. Hammel, E. R. Grilly, J. G. Dash, R. D. Taylor, R. H. Sherman, E. C. Kerr, A. F. Schuch, T. R. Roberts and S. G. Sydoriak. All the material presented has been thoroughly discussed with these individuals, and, indeed, ideas for some of the arguments given were conceived by them. I am grateful for their help and criticism. In addition, it is a pleasure to acknowledge as a source of information and stimulation helpful discussions with J. R. Clement, R. P. Hudson, E. Ambler, H. van Dijk and M. Durieux. This work was performed under the auspices of the U.S. Atomic Energy Commission.

1 Van Dijk, H., and Shoenberg, D., Nature, 164, 151 (1949).

${ }^{2}$ Bleaney, B., and Simon, F., Trans. Farad. Soc., 35, 1205 (1939).

'Schmidt, G., and Keesom, W., Physica, 4, 971 (1937).

${ }^{4}$ Kamerlingh-Onnes, H., and Weber, S., Leidlen Commun., 147b (1915).

${ }^{5}$ Kistemaker, J., and Keesom, W., Physica, 12, 227 (1946). Kistemaker, J., Physica, 12, 272 (1946).

- Erickson, R., and Roberts, L., Phys. Rev., 93, 957 (1954).

'Corak, W., Garfunkel, M., Satterthwaite, C., and Wexler, A., Phys.

Keller, W., Phys. Rev., 97, 1 (1955) ; 98, 1571 (1955).

- Clement, J., Logan, J., and Gaffney, J., Phys. Rev., 100, 743 (1955). ${ }^{10}$ Berman, R., and Swenson, C., Phys. Rev., 95, 311 (1954).

${ }^{11}$ Moessen, G., Aston, J., and Ascah, R., J. Chem. Phys., 2f, 2096 (1954).

${ }_{12}$ Swenson, C. (private communication to Clement).

${ }^{13}$ Kilpatrick, J., Keller, W., and Hammel, E., Phys. Rev., 97, 9 (1955).

${ }^{14}$ Clement, J., Logan, J., and Gaffney, J., Naval Research Laboratory Report No. 4542, May 1955

${ }^{15}$ Ambler, E., and Hudson, R., J. of Research, Nat. Bur. Stand., 56, $99(1956)$.

16 Dana, I., and Kamerlingh-Onnes, H., Leiden Commun., 179 c (1926).

17 Berman, R., and Poulter, J., Phil. Mag., 43, 1047 (1952).

${ }^{18}$ Keesom, W., and Schmidt, G., Physica, 4, 963 (1937).

${ }^{10}$ Keesom, W., and Clusius, K., Leiden Commun., $219 \mathrm{e}$ (1932).

${ }^{20} \mathrm{Keesom}, \mathrm{W}$., and Keesom, A., Leiden Commun., 235 d (1932).

21 Keesom, W, and Keesom, A., Physica, 2, 557 (1935).

22 Kramers, H., Wasscher, J., and Gorter, C., Physica, 18, 329 (1952).

${ }^{23}$ Hercus, G., and Wilks, J., Phil. Mag., 45, 1163 (1954).

${ }^{24}$ Clement, J. (private communication).

${ }^{25}$ Ambler, E., and Hudson, R., J. of Research, Nat. Bur. Stand., $5 \%, 23(1956)$

20. Long, E., and Meyer, L., Phys. Rev., 83, 860 (1951).

${ }_{27}$ Dash, J., and Taylor, R., Phys. Rev., 99, 598 (1955).

\title{
SCIENTIFIC AND ENGINEERING MAN-POWER IN GREAT BRITAIN
}

$\mathrm{T}$ HE recently issued report on scientific and engineering man-power in Great Britain* embodies the results of two related inquiries. The results of the first, initiated by the Ministry of Labour and National Service, and carried out with the help of the Social Survey, which was concerned with the present number and distribution of scientists and engineers, and with the demands of industry

* Scientiflc and Engineering Manpower in Great Britain a a Report on the Number and Distribution of Scientists and Engineers now employed in Great Britain, and a Study of the Likely Trend in the H.M.S.O., 1956.) 1s. Bd. net. and the other main users of scientific man-power in three years time, are set out in the second part of the report. The second study, the conclusions of which are given in the third part, was made by the Committee on Scientific Man-power of the Advisory Council on Scientific Policy and was concerned with the probable trend in the long-term demands for scientists and engineers. Its purpose is to set a goal for the universities and the technical colleges of Britain, so that present and future demands for trained scientific man-power may be met. 
In the present inquiry, the terms 'scientist' and 'engineer' are used to cover the basic sciences on one hand and the applied sciences in the engineering field on the other. The term 'scientist' in this report covers biology, chemistry (other than pharmacy), geology, mathematics, physics, and general science, while the term 'engineer' covers persons with a degree or other professional qualification in chemical engineering, civil and structural engineering, electrical engineering, mining engineering, mechanical, aeronautical and other branches of engineering, and metallurgy. The report thus excludes those who have studied science at the universities but qualified in agricultural science, dentistry, medicine and veterinary science, and it does not include people with specialized qualifications in certain fields of technology such as textiles and rubber. The social sciences are likewise excluded. Its attention is concentrated on the demand for 'qualified' scientists and engineers, and this is taken to mean those with a university degree in these fields or who are associates of certain bodies such as the Manchester College of Technology, or corporate or graduate members of the professional institutions listed.

The Ministry of Labour's inquiry was linked with an inquiry on behalf of the Department of Scientific and Industrial Research into the proportion of industry's resources spent on research. Information was obtained from all manufacturing establishments employing 500 workers or more, and from a sample of those with between 100 and 499 workers. Establishments with less than a hundred workers were not approached. Slightly different sampling arrangements were used in the building and contracting industry ; information was obtained from the boards of nationalized industries, central government departments and local authorities, but agriculture, the nonnationalized parts of the mining and transport industries, shipping, the distributive trades and miscellaneous service industries were not covered.

For early 1956 the inquiry gives the total of qualified scientists as 51,230 and of qualified engineers as 119,700 , of whom 32,150 possess higher national certificate or diploma or its equivalent; and of these last, 22,790 are employed in manufacturing industry, 5,330 in nationalized industries (including the Atomic Energy Authority), 1,710 by the central government and 320 by local authorities. For qualified engineers as a whole, the corresponding figures are $37,000,14,660,8,050$ and 6,330 , with a further 2,430 in education; and for qualified scientists, $17,050,2,420,5,800,350$ and 25,610 . Rough estimates put the number of qualified scientists in other employment at 5,000 and of qualified engineers at 10,000 , making a grand total of 134,700 . Besides this, there are about 4,700 qualified scientists and 2,300 engineers engaged in postgraduate research at the universities or at present on National service.

of the 134,700 qualified scientists and engineers, or about 0.6 per cent of the working population of 24 million, there are thus about 43 per cent in manufacturing industry, 12.5 per cent in the nationalized industries, 21 per cent in teaching, 10 per cent in central government establishments, 5 per cent in local government, and 8 per cent in miscellaneous occupations. Nearly half the qualified scientists are engaged in teaching, and three-quarters of the qualified engineers are in industry.

These scientists and engineers are concentrated in a relatively fow industrial groups. Of 48,829 engineers and scientists in manufacturing industry, the num- bers were distributed as follows : chemicals $(8,300)$, other plant and machinery $(6,700)$, electrical engineering $(12,200)$ and aircraft manufacture $(4,300)$, accounting for only three-tenths of the labour force, and include nearly two-thirds of the scientists and engineers. While the average proportion of scientists and engineers to the total employed is 0.8 per cent for all industries, it varies widely from one industry to another; from 10.9 per cent for the Atomic Energy Authority (for which the total in 1956 was 2,467, of whom 1,706 were engaged in research and develop. ment) to as little as 0.4 per cent in shipbuilding and motor manufacture and less than 0.25 per cent in cotton, wool and wood, cork, paper and printing. Only in mineral-oil refining $(5 \cdot 2)$, the electricity authorities $(2 \cdot 9)$, chemical and allied trades $(2 \cdot 7)$, electrical engineering $(2 \cdot 0)$, aircraft manufacture $(1 \cdot 9)$, constructional engineering $(1 \cdot 5)$, Gas Council and area boards ( $1 \cdot 2)$, non-ferrous metal manufactures $(1 \cdot 1)$, rayon, nylon, etc. $(1 \cdot 1)$, and other plant and machinery is it 1.0 per cent or more.

Of the 13,900 scientists and engineers in government service, just over a half are in the defence departments (including the Ministry of Supply), just over a quarter in the Civil departments, and onesixth in the Department of Scientific and Industrial Research, the Agricultural Research Council, the Medical Research Council or the Nature Conservancy. Of the 6,700 employed by local authorities (other than for teaching) 80 per cent are civil engineers. Of the 25,600 scientists and 2,400 engineers engaged in teaching, 13 per cent are in the universities, and of those teaching in schools more than a quarter are in Scottish schools.

Of those employed in manufacturing industry, about 45 per cent were engaged in research and development, 47 per cent in production, maintenance and installation and the remainder on 'other work', many of whom may not be engaged directly on any form of scientific or engineering work. So far as the figures go, they suggest that well above average proportions are engaged in research and development in the aircraft, electrical engineering, precision instruments, etc., and rayon, nylon, etc., industries, and well below average in shipbuilding and repairing, railway equipment, iron and steel, non-ferrous metai, and other plant and machinery.

Dealing next with the demand for scientists and engineers in the next three years, the report gives the 1959 requirements of industry in Britain at 94,640 -an increase of 33 per cent-the increase in manufacturing industry, building and contracting, research associations and nationalized industries (including the Atomic Energy Authority) being given as $37 \cdot 0,32 \cdot 0,21 \cdot 0$ and $22 \cdot 0$ per cent, respectively. For government departments, local authorities and teaching, an increase of 14.0 per cent for 1959 to 55,400 is reported. For the central government, the increase from 13,850 to 15,850 is mainly in the research departments ( 23.0 per cent), compared with 12.0 per cent in defence departments and 14.0 per cent in civil departments. For local authorities an increase of 27.0 per cent is reported and for teaching 11.0 per cent, of which 34.0 per cent is estimated for the universities, though this figure is conjectural, being estimated before the University Grants Committee had received the universities estimates for $1957-62$.

Among eategories of scientists, the greatest numerical increase in the next three years is estimated for chemists $(4,500$ or 22 per cent), physicists coming 
next with 2,400 (23 per cent), and mathematicians with 1,500 (13 per cent). For biologists the figures are $600(12.5$ per cent) ; for geologists, $200(22.0$ per cent); and for other scientists, 300 (11.0 per cent). Among engineers the greatest demand in numbers is expected for mining and other engineers $(8,800$ or $33 \cdot 0$ per cent), for electrical engineers $(5,100$ or $23 \cdot 0$ per cent) and for civil engineers $(3,400$ or $27 \cdot 0$ per cent). For metallurgists the figures are 1,200 (38.0 per cent); mechanical engineers, 1,000 (26.0 per cent); chemical engineers, $700 \quad(47 \cdot 0$ per cent); and for engineers in teaching, $600(25 \cdot 0$ per cent).

The Committee on Scientific Man-power bases its assessment of the long-term demand for scientists and engineers on the assumption of an overall expansion of industrial output of 4 per cent a year, and that this is only possible if there is an adequate supply of scientists and technologists. This involves assumptions of increases of 7 per cent and $5 \cdot 25$ per cent for the chemical and engineering industries, whereas only 2.5 per cent is assumed for the textile industry. Replies received to the Ministry of Labour questionnaire indicate that, without qualification, manufacturing industry expects to employ 37 per cent more scientists and engineers in 1959 than in 1956 ; but this figure reflects a considerable margin for current shortages of qualified men. The Committee attempted to isolate this element by assuming that the demand for trained man-power in each industry would, at the least, rise in relation to the number now employed by the same proportion as output is expected to do over the next three years. The difference between this estimate and the figure supplied by industry is taken to represent the presumed current shortage; and an allowance for this factor has been added to the number currently employed, before making the extrapolations based on changes in output over the next ten years. The result is an estimate of the demand for scientific man-power in terms of the number of scientists and engineers necessary to permit an increase in industrial output of 4 per cent per annum.
The estimates for government departments are based on existing policies and allow only for a very modest increase over the next ten years. Sufficient teachers are postulated to deal with the increased number in secondary schools, but not for any further concentration on scientific subjects or for any improvement in existing staffing ratios, for which about four thousand additional science graduates would be a reasonable assumption. Requirements of the universities are assumed to increase by about 100 per cent over the period.

The broad conclusion is reached that an increase of rather more than 60 per cent is required--from about 135,000 to about 220,000 in 1966 -the increase for engineers being about 70 per cent and for scientists about 50 per cent. The annual gross flow of those qualified in pure and applied science from the universities and technical colleges is to-day a little more than 10,000 -roughly about half scientists and half engineers-and this could well rise to 12,000 by $1958-59$. During the next five years, some 60,000 people qualified in science and engineering might come from the universities and technical colleges of Great Britain; but this would have to rise to 16,000 a year if the figure of $22,0,000$ is to be reached by 1966. Allowing 25 per cent for overseas students, emigration, etc., and some continued measure of shortage, the Committee estimates that an annual output of 16,900 in 1966 and 19,900 in 1970 is required.

The Committee recognizes that its estimates involve some margin of error, but it points out that it may well have taken too conservative a view of the demand that is likely to develop in some sectors of the economy. It suggests, however, that the estimates point to a reasonable objective for the universities and technical colleges. In conclusion, the Committee emphasizes that, at the national level, an annual figure of 'graduations' in pure and applied science of about 20,000, as compared with the present 10,000 , is the minimum at which we should aim over the next ten to fifteen years, if the economy of Britain is to grow at an acceptable rate.

\section{METALS IN LIVING SYSTEMS}

A SYMPOSIUM on "Metals in Living Systems" occupied the morning session on September 3 of Section B (Chemistry) during the recent Sheffield meeting of the British Association. It was opened by Sir Rudolph Peters with a few remarks about the role of metals in a variety of enzyme reactions and the importance of metals for the metabolism of all forms of life. He gave some examples of how the biochemist could elucidate the actual function of a metal in an enzymic reaction. In particular, he mentioned the importance of the complex formation between metals and sulphydryl groups as shown, for example, in the interaction of ferrous iron, cysteine and aconitase, studied in his laboratory by Morrison. Sir Rudolph emphasized the complexity of some of the problems by referring to the recent work on the composition of xanthine oxidase.

Prof. A. Neuberger (London) discussed the structure and biogenesis of porphyrins and related compounds. Simple pyrroles have so far not been found in Nature, with the notable exception of the aminomethyl pyrrole, porphobilinogen, which is an intermediate in the biosynthesis of porphyrins and is excreted in the urine of patients suffering from acute porphyria. Much more widespread - and of the greatest im. portance in connexion with the present discussionare the macrocyclic tetrapyrrolic structures found in hæmoglobin, chlorophyll and vitamin $\mathrm{B}_{12}$. Prof. Neuberger first discussed the porphyrins forming part of the hæmoglobin, catalase and peroxidase molecules and the type of resonance found in the porphyrin structure. He then briefly considered the types of bond formed between the central iron atom in hæm and the heterocyclic pyrrolic systems. The interaction between the hæm and protein moiety of the hæm proteins was considered and the various types of isomers arising from changes in the order of the 'outer' substituents of the porphyrin ring were mentioned. Turning to the chlorophylls, Prof. Neu. berger pointed out that these contain as the central atom not iron, but magnesium, and also differ from the hæm compounds in the degree of saturation of the heterocyclic system. The work of linstead and his co-workers on the location of the 'extra' hydrogen 